\title{
Geomorphologic Structure, Characteristics and Processes in the Cangshan Mountains: Explanations for the Formation and Development of the Dali Glaciation*
}

\author{
Ye Wan ${ }^{1}$, Kaidao $\mathrm{Fu}^{2}$, Yong $\mathrm{Liu}^{3}$, Zhengtao $\mathrm{Shi}^{3}$ \\ ${ }^{1}$ Yunnan Institute of Geography, Yunnan University, Kunming, China \\ ${ }^{2}$ Asian International Rivers Center, Yunnan University, Kunming, China \\ ${ }^{3}$ College of Tourism and Geographic Sciences, Yunnan Normal University, Kunming, China \\ E-mail: kdfu@ynu.edu.cn
}

Received March 14, 2011; revised April 17, 2011; accepted May 9, 2011

\begin{abstract}
The area around Cangshan Mountain, located on the southeastern fringes of the Tibetan Plateau, is a key region in terms of revealing the processes involved in the uplifting of the Tibetan Plateau, plus its environmental effects. Based on systemic field and laboratory work, this study uncovers the step-like geomorphologic structure, characteristics and processes revealed in the Cangshan Mountain area, to argue for the formation and development of the Quaternary glaciation there. The results indicate that there were two paleo-glaciations in the area, which were the early and late Dali Glaciations, and that these occurred during the time periods $5.76 \times 10^{4} \mathrm{aBP}$ and $1.6 \times 10^{4} \mathrm{aBP}$ respectively, being the southernmost paleo-glaciations to have taken place in China. Two step-like paleo-planation surfaces were formed vertically at the mountain (that is, at the summit of Cangshan, which is 3800 to $4000 \mathrm{~m}$ above sea level (a.s.l) in height; and at the paleo-glacial and peri-glacial active zones: 3700 to $3900 \mathrm{~m}$ a.s.l. in height). Meanwhile three widespread erosion surfaces can be identified at about 2900 to $3500 \mathrm{~m}, 3000$ to $3100 \mathrm{~m}$ and 2450 to $2550 \mathrm{~m}$ a.s.l. in height; three fluvial fans developed on the landform at about 2250 to $2200 \mathrm{~m}, 2200$ to $2150 \mathrm{~m}$ and 2150 to $2100 \mathrm{~m}$ a.s.l. in height respectively, and lacustrine relief developed surrounding the Erhai Lake.
\end{abstract}

Keywords: The Dali Glaciation, Step-Like Landform, Cangshan Mountain

\section{Introduction}

The Yunnan-Guizhou plateau, located on the famous Mediterranean-Himalaya orogen, was activated and tilted by the Tibetan plateau uplift and the Himalaya orogenic movement after the Neogene period, so that the Yunnan-Guizhou plateau rose in the form of both a lift-stop and a block-uplift, and its landforms are now characterized by plateau-block faults, with deep mountain incised valleys, interspersed with lake basins. Cangshan Mountain (about $4122 \mathrm{~m}$ a.s.l ), lies in the tilted uplifted area of western Yunnan and in the southeastern part of the Hengduanshan Mountains, and is a step-like block mountain with parallel mountainous ridges and valleys (Fig-

*Supported by National Natural Science Foundation of China (NSFC) grant (No.40801218); Yunnan Province Natural Science Foundation (2008 CD 073); and Project of Young-Middle Aged Academic Leader Candidates of Yunnan Province (2009CI050). ure 1).

Cangshan Mountain and the glaciation on its peak are important clues to use to explore the process of glaciation that has taken place on the Tibet plateau and the evaluation of continental glaciers in southwest China. Much research has been conducted in order to better understand the formation of Cangshan Mountain and the Dali glaciation by both foreign and domestic scholars. First, H.von, a famous German geographer, was the first to name the glacier as the 'Dali glacier' at the latter end of the 1930s [1]. Next, the Chinese glaciologist Shi Yafeng stressed its importance in terms of the glaciological field [2], and the formation of the mountain and the glacier also attracted much attention from other scholars whose research was focused on the Tibetan Plateau [3].

The development of Cangshan Mountain and the formation of the Dali Glacier have attracted much more 


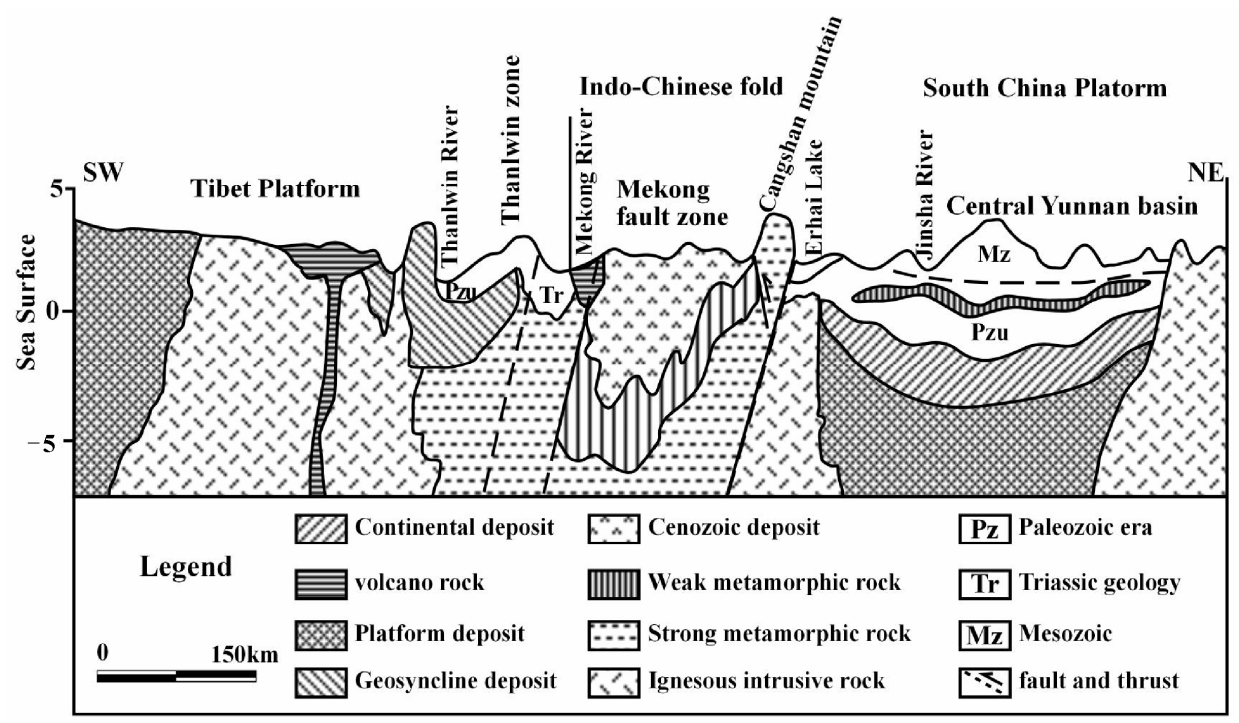

Figure 1. The background of geology of the Cangshan Mountain.

attention from geomorphologists and geologists worldwide since the 1970s. L.V. Loczy, a famous Hungarian scholar, explored Yunnan via southern Tibet and western Sichuan early in the last century, investigating the glacial landscape and the distribution of the moraines [4]. A British scientist named F. K. Ward devoted his time to exploring the development of the glacier and river valleys in the Three Parallel Rivers region, located in northwest Yunnan Province, focusing many of his reports on this issue after 1913 [4]. J. Coggin Brown carried out an extensive survey on the geological and geomorphological background of the Yunnan plateau, in particular observing the geomorphology of the Dali area [4]. Meanwhile, Gregory spent his time observing the geological setting in northwest Yunnan, and a more detailed scientific expedition was carried out by W. Credner in his "Report of a Yunnan Geographic Expedition" in 1930 [4]. Credner's results were published in Natural Science and suggested that the Xima pool (a small, circular lake) at the Zhonghe summit is a cirque lake [5]. In the late 1930s, H. Von Wissman referred to the glaciation at Cangshan and Yulongshan Mountains many times in his publications, in particular The Pleistocene Glaciation of China, and as a result put forward the concept of a Dali Glaciation [2,5]. Mitch investigated Yunnan from 1940 to 1947 and wrote the books: A Geological Survey of Yunnan and The Tectonic history of Yunnan and Geology of Lijiang [6]. At the same time, Feng Jinlan, a Chinese scholar, provided his understanding of the evolution of the landforms, geomorphology and physiography in the region [7]. Later, Chen Fubin studied the Quaternary accumulation, the geomorphology and neo- tectonic activity around Cangshan and Yulongshan Mountains [8].
It is important to review and confirm the facts regarding the formation and evolution of Cangshan Mountain and the Dali glacier by going through the contrasting research work in other regions, and the results of this review will help give important clues as to the climatic effects caused by the Tibetan uplift [9]. As a result, our research work has included systemic field and laboratory work, in order to gain more intelligence on this issue since the mid to late 1990s.

\section{The Vertical Geomorphic Structure and Characteristics of Cangshan Mountain}

\subsection{Paleoplanation Surfaces}

The paleoplanation surfaces, formed in the Paleogene period, are from an uplifted peneplain which is low in gradient and scattered across the mountainous and plateau areas in central and western China, but is distributed continuously around the Tibetan Plateau [10,11]. According to the research by Li et al. [12], the main planation surface on the Tibetan Plateau was formed at about $1000 \mathrm{~m}$ a.s.l. during the Pliocene and late cenozioc periods. The present surface, at about $4500 \mathrm{~m}$, is the best preserved planation surface in China, and this extends from the Tibetan Plateau and northern Hengduanshan Mountains, to Lijiang and Dali in western Yunnan at a height of around $4500 \mathrm{~m}$, falling to about $2000 \mathrm{~m}$ around the Kunming region in the central Yunnan-Guizhou Plateau. This hierarchy landform indicates that ancient tectonic activity was widely associated with neo-tectonic action in the region. From the mountain summit to the river valley, there are glaciers, lake basins and fluvial landscapes. The plateau surface has been dissected with 
alternating mountain ranges and valleys in northwest Yunnan, due to the block-fault uplifts of the mountains and the deep incisions of the rivers. At present, the summit surface in Yulongshan is between 5000 and $5200 \mathrm{~m}$ in height and at Cangshan, it is 3750 to $4000 \mathrm{~m}$ in height, these being the remnants of the highest paleoplanation surface (Figure 2). Jianchuan red clay, which is mainly distributed around the Dali and Lijiang regions, was formed during the late Tertiary period, and is contemporaneous with the Panzhihua red clay which developed in the southwest Sichuan basin. In contrast to the Jianchuan clay stratum, an ancient peneplain developed in the Dali basin surrounding the Erhai Lake, where thick Songmaopo formations were deposited above the peneplain and developed into lacustrine sediment. In accordance with previous research, the bottom of the Songmaopo Formation dates from $330 \times 10^{4} \mathrm{aBP}$, during the beginning of the dissection of the Dali planation surface and block-fault uplift of Cangshan Mountain. At the same time, Erhai Lake started to develop, and Cangshan Mountain was uplifted from $700 \mathrm{~m}$ a.s.l. to $4000 \mathrm{~m}$ a.s.l. - its present position. The mountain range has therefore been lifted about $3300 \mathrm{~m}$ since $330 \times 10^{4} \mathrm{aBP}$, to become the highest planation surface in the Dali area (Table 1).

This planation surface has been eroded by ice and water, so the remnants are revealed in the form of alternating mountain ranges and valleys, with thin modern glaciers over the top. As a result glacial rock, gelifluction and frost heaving hillocks can be investigated on the surface.

\subsection{The Cold Geomorphic Process and the Paleoglacial and Periglacial Zone}

Cangshan Mountain is located in a subtropical zone, where it rains broadly in the summer and autumn under the influence of the southeast Pacific monsoon and the Indian Ocean's warm and humid climate. The land, temperature and snowfall conditions all help in the development of glaciers in these high-elevation mountains. At a height of 3700 to $3900 \mathrm{~m}$, the dominant paleoglacial, periglacial and modern fluvial processes are active (Figure 2). Incision by fluvial processes, frost weathering, and collapse and block movements, are the main external geomorphologic processes that take place in the Cangshan Mountain area. The rock strata are mainly composed of Precambrian metamorphic rock, which constitutes the core of the mountain and is overlaid by a thin layer of weathered rocks and sub-high mountainous meadow soil. Ren Meie et al. [13] and Shi Ya- feng et al. $[14,15]$ argued that the snowline for the last glaciation in Dali was $3900 \mathrm{~m}$. The oceanic climate has been more helpful in the development of glaciers than the continental climate; therefore, it is possible that the last glacial snowline at Cangshan Mountain would have dropped about 100 to $150 \mathrm{~m}$ to reach a height of 3800 to $3750 \mathrm{~m}$. Based on this research; however, the eastern slope of Cangshan Mountain appears to be steeper than the western slope, and through the use of aerial photographs, 65 cirques have been identified on Cangshan Mountain, plus three glacial lakes, two glacial basins and six nivation hollows. These are distributed between Wutai summit in the northern part of the Mountain and Shengying summit, in the southern part - between Yingle summit and Malong summit. There are 47 cirques on the eastern slopes of Cangshan Mountain, and eighteen on the western slopes [16], the greater number in the east due to differences in landforms and precipitation. First, in terms of the relief structure of Cangshan Mountain, the eastern slope is steeper, so there are more horns and arêtes, plus, interestingly, there are erosion roofs distributed near the fault cliffs, formed by glacial and periglacial processes,

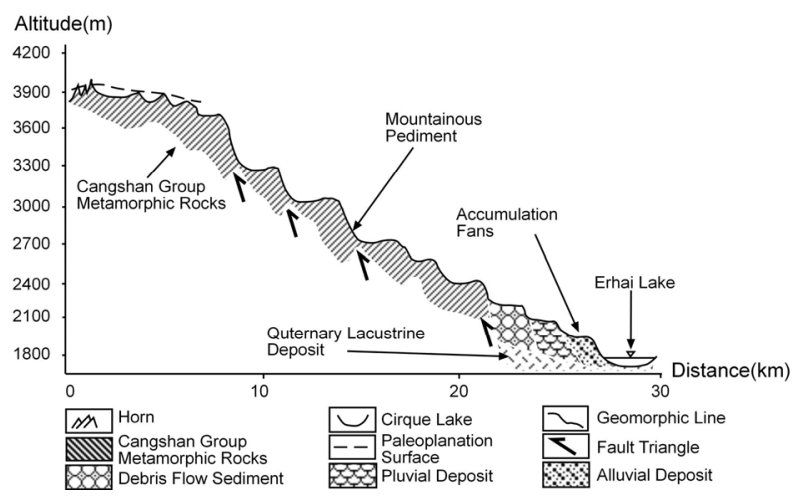

Figure 2. The profile map of vertical geomorphologic development of the eastern slope in the Cangshan Mountain.

Table 1. The stratum structure and the extent of the planation surfaces in the Dali and Lijiang areas.

\begin{tabular}{clccc}
\hline Region & \multicolumn{1}{c}{ Stratum } & $\begin{array}{c}\text { Age } \\
\text { (Ma) }\end{array}$ & $\begin{array}{c}\text { Height of the Paleoplanation } \\
\text { Surface (M a.s.l.) }\end{array}$ & $\begin{array}{c}\text { Height of the Remaining } \\
\text { Planation Surfaces (M a.s.l) }\end{array}$ \\
\hline \multirow{2}{*}{ Hali Area } & $\begin{array}{l}\text { Paleoplanation surface-Songmaopo } \\
\text { lacustrine sediment-Jianchuan red } \\
\text { clay }\end{array}$ & 330 & 700 & 4000 \\
Lijiang & $\begin{array}{l}\text { Paleoplanation surface-Songmaopo } \\
\text { Area }\end{array}$ & $\begin{array}{l}\text { lacustrine sediment-Jianchuan red } \\
\text { clay }\end{array}$ & 330 & 700 \\
\hline
\end{tabular}


and these landforms facilitate the formation of cirque glaciers. Secondly, although Cangshan Mountain is high and has an almost north-south alignment, it is not long enough to block the water vapor from crossing from one side of the mountain to the other, something which is very different from the other mountains in the area, such as Yulong Mountain and Haba Mountian, where precipitation on the western slope is greater than on the eastern slope. When water vapor moves across to the eastern slope, it is uplifted by the Erhai cold anticyclone, leading to greater precipitation on the eastern slope. Annual precipitation is $1081 \mathrm{~mm}$ at Yangbi weather station on the western slope, is $1078 \mathrm{~mm}$ in Dali town, on the eastern slope, and is $1052 \mathrm{~mm}$ in Xiaguan [17]. The data indicates that precipitation on the eastern and western slopes is almost equal statistically, showing the special nature of the local rainfall, which is caused by Cangshan's geomorphic structure being dominated by the south-western monsoon. The particular landform and precipitation has resulted in more cirques developing on the eastern slope than on the western slope. Our knowledge of glacier characteristics [2,5], as well as the detailed field and indoor work carried out, proves that the development of glacial erosion landforms in the study area mostly took the form of cirques, and that the paleoglacier which developed on Cangshan Mountain can basically be characterized as a hanging oceanic cirque glacier. Through surveys it has been established that the ancient cirques are distributed in two tiers along the two sides of the ridge, and the height of the higher tier of cirques is at about 3800 to $3950 \mathrm{~m}$, and the lower tier is at about 3800 to $3850 \mathrm{~m}$, with the length and width of the cirques being about 250 to $400 \mathrm{~m}$ and 300 to $500 \mathrm{~m}$, respectively (Table 2). The Lanfeng cirque is the most typical, as, located at about $3900 \mathrm{~m}$ there are obvious anti-slope and crosswalls at the bottom of the cirque, the length and width of both being $500 \mathrm{~m}$. Able to be seen clearly from Xizhou, a town on the shores of Lake Erhai, two cirque lakes, Huanglong pool at about $3880 \mathrm{~m}$ and Heilong pool at about $3850 \mathrm{~m}$, developed between Lanfeng and Sanyangfeng summits (Table 2). Lanfeng peak is a typical arête, with a huge-filled stone glacier having developed at the back wall, and with periglacial sediment deposited at the bottom of the cirque. Another typical cirque is Ximatan pool, located on Yuju summit and at a height of about $3840 \mathrm{~m}$, where there are debris slopes, stone-filled glaciers and frost hillocks at the back wall of the cirque. The round lake referred to by Credner, Wissmann and Feng Jinglan, is actually the Ximatan cirque [2,5,7], which has been preserved well in terms of its shape and has not been incised by fluviation. The ESR age of the sediment at Shuangtangzi cirque is $1.6 \times 10^{4} \mathrm{aBP}[16,18]$, and is deemed to have been formed during the late of Dali ice epoch of the Pleistocene period. At that time, seven cirques were formed and most of them are distributed to the east of the mountain, and are associated with six nivation hollows.

Based on field survey, three types of periglacial were found on the Cangshan Mountain. Debris slopes, stonefilled glaciers mainly formed within the cold geomorphologic active zone where elevation is above $3700 \mathrm{~m}$. The slopes and stone-filled glaciers are about $10-20 \mathrm{~m}$ long, and the about 50 - $80 \mathrm{~m}$ wide. Most distribute on summits with altitude above $4000 \mathrm{~m}$, such as Malong summit, Lanfeng summit, Sanyang summit, Yuju summit and Longquan summit. Frozen expanded hillocks with the diameter around $50-70 \mathrm{~cm}$ and height about 20 $30 \mathrm{~cm}$, mainly distributed on the ridge between two peaks where the Paleoplanation surface lies. Periglacial vestiges found in eastern slope of Cangshan Mountain aremore than those in western slope. We argue that the condition of landform, precipitation and temperature in eastern

Table 2. Parameters and characteristics of the glacial landforms.

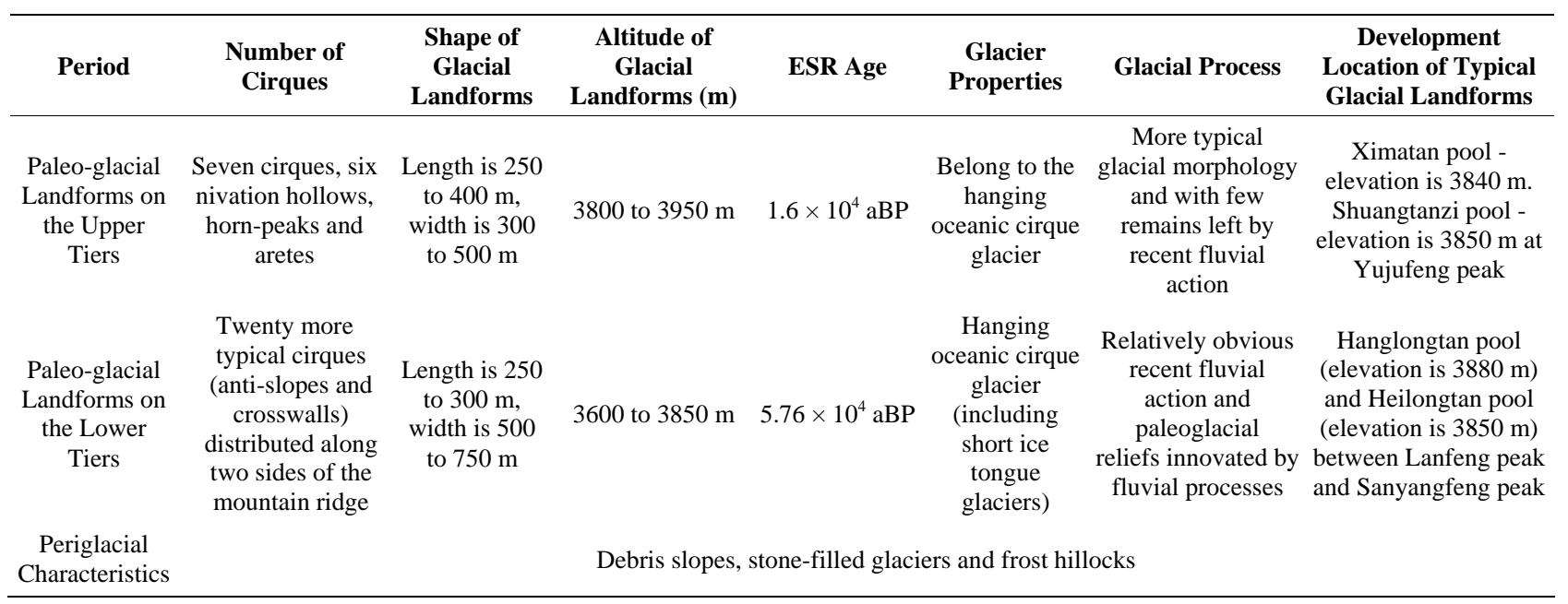


slope are more suitable for periglacial geomorphology development.

The lower tier of cirques is located between 3700 and $3850 \mathrm{~m}$ and is larger in scale, with the lower of these located at $3750 \mathrm{~m}$ and with a length of between 250 and $300 \mathrm{~m}$, and a width of between 500 and $750 \mathrm{~m}$ (Table 2). A thin layer of sediment has been deposited at the bottom of the cirques, which are dominated by plants such as azalea. Most of the cirque crosswalls have been cut into by fluvial incision. A cirque lake formed during the glacial epoch has since shrank and gradually dried up. The Shuanglongtan pool; for example, was caused by backward fluvial incision to the source, and has since turned from one large pool into two smaller ones. Using aerial photography, twenty seven cirques can be observed on the eastern slope and three on the western slope. The ESR age of the sediment deposited at the bottom of the Yunnong summit cirque, which is located at a height of $3600 \mathrm{~m}$, can be dated back to $5.76 \times 10^{4} \mathrm{aBP}$ $[16,19]$, at the early stages of the Dali ice epoch.

\subsection{Mountainside Fluvial Incision}

The erosion surface in the area is the planation surface which has been uplifted and dissected on to the earth's surface [11-12]. There are several pediments on Cangshan Mountain at a height of between $2400 \mathrm{~m}$ and $3700 \mathrm{~m}$, due to the phased block uplift of the Mountain during the Quaternary period. Field investigations of the erosion surface on the Mountain, have found at least six erosion surfaces at heights of $3600 \mathrm{~m}, 3100 \mathrm{~m}, 2800 \mathrm{~m}, 2600 \mathrm{~m}$, $2500 \mathrm{~m}$ and $2400 \mathrm{~m}$. This series of erosion surfaces has been incised by streams on the eastern slope, revealed by alternating erosion surfaces and cliff pools. In general, the conjunction of the surface and cliffs is presented as typical fault triangles at a height of 2800 to $2900 \mathrm{~m}$ at Qinglinfeng summit, and about 2900 to $3500 \mathrm{~m}$ at $\mathrm{Yu}-$ jufeng summit. Two larger erosion surfaces exist at a height of 2450 to $2550 \mathrm{~m}$ and at 3000 to $3100 \mathrm{~m}$ on the respective summits (Figure 2).

The geomorphic processes along the mountain have been dominated by slope flows (waterfall and sheet flows), and the front parts of the erosion surfaces are generally covered with thick residual material, with different thicknesses of alluvial and fluvial sediment on both sides of the valley. The sediment is poorly rounded and sorted, which can be mainly attributed to flood genesis.

\subsection{Mixed Deposition Process Zone on the Pediment}

Several deposition fans can be found in the fields on the eastern slopes of Cangshan. Based on the structure and composition of the sediment found there, they have been categorized as mixed depositions by researchers, because the sediment does not accord with the characteristics of the other types of sediment found [14,20]. As a result, this study will define and title the piedmont sediment as consisting of mixed deposition fans. There exist three grades of deposition fan which run from an altitude of $2100 \mathrm{~m}$ to $2400 \mathrm{~m}$ - arranged neatly from south to north. From top to bottom, the heights of the three deposition fans are 2250 to $2200 \mathrm{~m}, 2200$ to $2150 \mathrm{~m}$ and 2150 to $2100 \mathrm{~m}$ (Table 3). The highest fan meets the pediment, and has sediment covering it in the form of a thrust fault. As one moves from the higher to the lower fan, they grow younger, the gradients become less and the scale smaller.

The fan at about 2250 to $2200 \mathrm{~m}$ is mainly composed of large boulders, gravel and clay, and is poorly sorted, with long term deposits and is intensively clayizated. This fan has been incised by water and severely damaged, so that it is now contains non-continuous ridges and hills. The texture and sediment characteristics of the fan demonstrate that chiefly the dynamics of fan deposition have taken place, with debris and water-rock flows present (Table 3).

The fan situated at a height of 2200 to $2150 \mathrm{~m}$ is characterized by considerable sorting and layer features, and the South Baolin section can be used as an example. This section is about $8.5 \mathrm{~m}$ in depth, with the upper layer being about $2 \mathrm{~m}$ deep and covered by a layer of grey mixed deposits, of which the scree shows as poorly rounded and sorted stones with diameters ranging from 10 to $50 \mathrm{~cm}$. The middle layer of $1.5 \mathrm{~m}$ is composed of fine red gravel and has clear evidence of boulders between the upper and middle layers. The upper part, with a thickness of 20 to $40 \mathrm{~cm}$ is paleosoil, with clear eluviation. The lower layer of about $5 \mathrm{~m}$ is made of granite and balling boulders, produced by weathered limestone. Generally, the rocks in the low layer are 50 to $80 \mathrm{~cm}$ in diameter, though some of them exceed $1 \mathrm{~m}$. This fan is preserved better than the previous one mentioned. Neolithic ruins left by humans, aged about $3000 \mathrm{aBP}$, and a Bronze Age burial site from before $2000 \mathrm{aBP}$, can also be found in the mixed deposits in the fan. The fan is considered to have been produced by alluvial and fluvial processes (Table 3).

The fan located between 2150 and $2100 \mathrm{~m}$ is distributed continuously along the foot of Cangshan, running from north to south, and is covered mainly by farmland and residential districts. The ruins of the ancient city of Nanzhao, from before $1000 \mathrm{aBP}$, are located within this fan as well. Most of the component materials are sands, fine sands and clay, within which are some large boul- 
Table 3. The structure and genesis of the three deposit fans.

\begin{tabular}{|c|c|c|c|c|}
\hline Fans & Altitude/m & Characteristics & Composition & Genesis \\
\hline First Class Fan & $2250-2200$ & $\begin{array}{l}\text { Connecting with the pediment and with an } \\
\text { early relative age; distributed non-continuously } \\
\text { due to water flow incisions during the post- } \\
\text { glacial period. }\end{array}$ & $\begin{array}{l}\text { Composed of huge boulders, gravel } \\
\text { and clay; clay weathering action is } \\
\text { strong. }\end{array}$ & $\begin{array}{l}\text { Slope accumulation is do- } \\
\text { minant and pluvial depo- } \\
\text { sits are secondary. }\end{array}$ \\
\hline Second Class Fan & $2200-2150$ & $\begin{array}{l}\text { Connected to the first class fan plus the surface } \\
\text { layer is composed of rocks (boulder clays with } \\
\text { a diameter of about } 10-15 \mathrm{~cm} \text { ); has a poor de- } \\
\text { gree of rounding and a poorly developed sorted } \\
\text { action; also the middle layer of the profile is } \\
\text { about } 1.5 \mathrm{~m} \text {. Has one fine gravel accumulation } \\
\text { area. Where there is an obvious dividing layer } \\
\text { at between } 20 \text { to } 40 \mathrm{~cm} \text {, plus obvious eluviation } \\
\text { - can be considered as one paleopsoil layer. }\end{array}$ & $\begin{array}{l}\text { The middle layer of the profile is } \\
\text { about } 1.5 \mathrm{~m} \text {. Has one fine gravel } \\
\text { accumulation area where there is an } \\
\text { obvious dividing layer at between } \\
20 \text { and } 40 \mathrm{~cm} \text {., plus there is obvious } \\
\text { eluviation - can be considered one } \\
\text { paleopsoil layer. }\end{array}$ & $\begin{array}{l}\text { Debris flows; } \\
\text { water flow; } \\
\text { pluvial deposits. }\end{array}$ \\
\hline Third Class Fan & $2150-2100$ & $\begin{array}{l}\text { The relief shape of this fan is preserved better } \\
\text { than for the second class fan, and reveals con- } \\
\text { tinuous distribution along the Cangshan moun- } \\
\text { tain pediment. }\end{array}$ & $\begin{array}{l}\text { There is better classified action and } \\
\text { finer layer structures than in the } \\
\text { other classes of fan; is composed of } \\
\text { sand, fine sand and clay plus there } \\
\text { are a few boulders and huge rocks } \\
\text { present. }\end{array}$ & $\begin{array}{l}\text { The profile shows that the } \\
\text { pluvial process is domi- } \\
\text { nant and fluvial process is } \\
\text { secondary. } \\
\text { An obvious characteris- } \\
\text { tic is that it has transited } \\
\text { forward under the coas- } \\
\text { tal deposit process. }\end{array}$ \\
\hline
\end{tabular}

ders and gravels. Due to an interaction between mountain streams and the lakeshore zone, the geomorphology has fluvial, alluvial and lacustrine characteristics. In accordance with the structure and the origins of the fan, a gemorphologic transition from a proluvial, alluvial fan to a coastal plain can be identified (Table 3).

As Cangshan Mountain was uplifted dramatically after the Quaternary period, a time associated with frequent seismic activity, debris and erosion terrain of glaciers was formed on the mountain peak, but the corresponding and typical moraine sediment has not yet been found. However, huge stones with a diameter of 3 to $5 \mathrm{~m}$ are disseminated along the highway in Dali city, and have been identified as ancient glacial boulders. A large area of sediments, to the east of Santa Temple, ranging from 3 $\mathrm{m}$ to several millimeters in diameter, may have been the product of debris flow. The fan-shaped depositions at the bayou of 18 streams, characterized by roughly sorted and assembled pebbles, are deemed to be fluvial and alluvial sediments. This mixed deposition was formed by an interaction of ice boulders, ancient and modern debris flows, alluvial, proluvial and lacustrine processes, and other external forces. The varying dominant forces on the landform have resulted in specific materials and components appearing in the sediments; meanwhile, the giant stones distributed at the foot of the mountain are the product of storm debris flows, or may have been produced by weathering and other flow processes. The fine and middle grain sized materials within the debris flow deposition have been removed by the stream, so the giant stones stand alone and are a major landscape feature near

\section{to Dali town (Figure 3).}

\subsection{Human-Related Geomorphic Structures on the Lake Plain and Lakeshore Terraces}

Following the deposition of the three mixed fans, the area was dominated by the Erhai Lake Plain at a height of between 2100 to $1900 \mathrm{~m}$ and a width of about 1 to $3 \mathrm{~km}$. Settlements such as Dali and Xizhou developed during the Yuan Dynasty on the lakeshore plain, which indicates that the coastal plain was formed 700 to 800 years ago. The coastal plain sediment is about 10 to $20 \mathrm{~m}$ thick and contains greyish-yellow clay, compressed with gravel, grass and coal. Based on field observations, four terraces have been identified at the eastern foot of Cangshan Mountain. The fourth terrace, which is $2 \mathrm{~m}$ higher than the water level of the lake, has been identified as a basement terrace and is composed of fine lacustrine sand and peat soil, but the other three are all accumulation terraces. The height above the lake water level of these three terraces is $10 \mathrm{~m}, 15$ to $30 \mathrm{~m}$ and 40 to $80 \mathrm{~m}$ respectively, and they are covered by Lacustrine, alluvial and proluvial sediments from the bottom to the top. The terraces were all formed during the Holocene period and are closely related to local human activities. As the water level in Erhai Lake dropped and the coastal terraces uplifted each time, so human activities and the cultural landscape, including residential areas, farmland and roads, expanded in the direction of the Lake. This fact has also been proved by archaeological findings [21], which indicate that New Stone Age ruins from before 


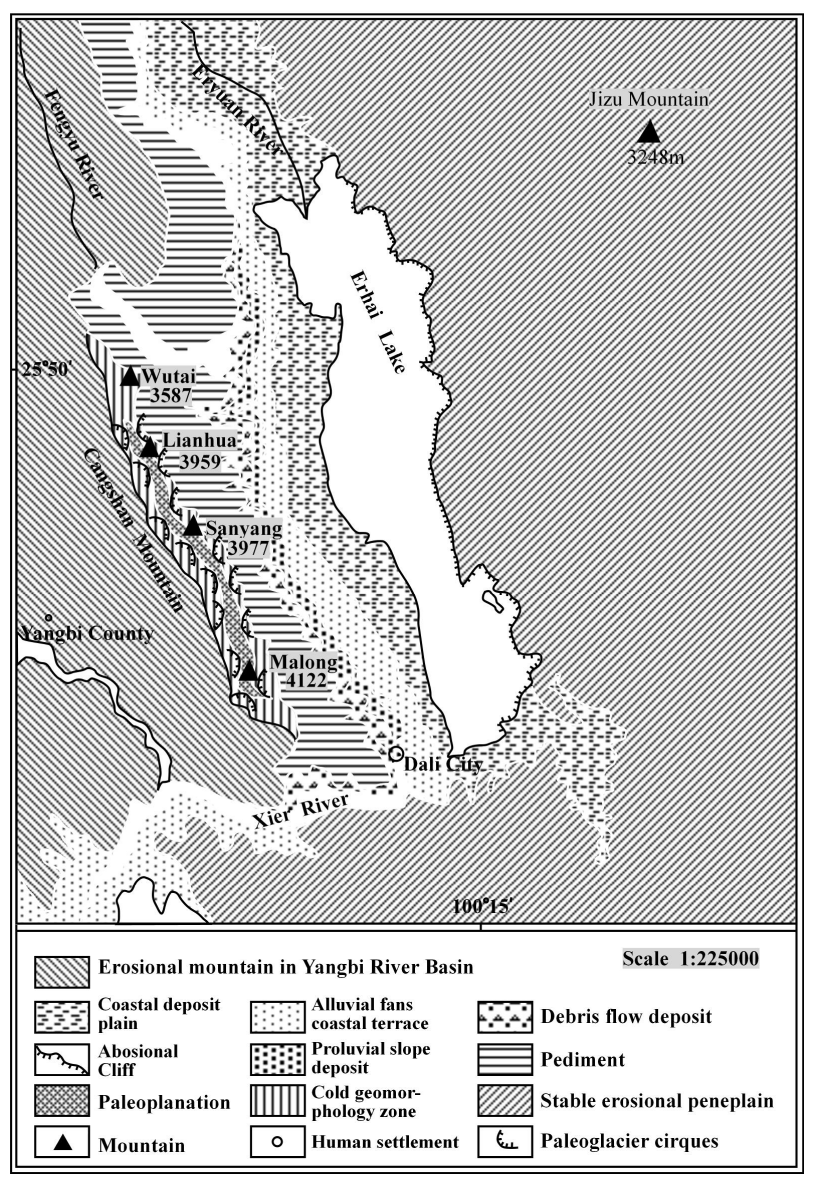

Figure 3. Map differentiating the geomorphologic structures and process classifications at Cangshan Mountain and its adjacent mountain, in Yunnan Province.

$3000 \mathrm{aBP}$ and Bronze Age burial mounds from before $2000 \mathrm{aBP}$ existed on the third terrace, but then the ruins of Nanzhao from about 1000 aBP moved to the lower second terrace, and settlements from the Yuan and Ming Dynasties then moved to the second terrace. This is a cultural landscape pattern created by humans adapting to changes in the natural environment, and in order to take full advantage of it.

A profile map of the vertical geomorpholoical development of the eastern slope of Cangshan Mountain is shown in Figure 2. A typical inland plateau lakeshore erosion landscape has formed on the eastern shore of Erhai Lake, instead of on the plain, with capes, bays and eroded cliffs distributed from east to west along the banks of the lake. The relative height from the top of the cliff to the lake water level is from $100 \mathrm{~m}$ to $150 \mathrm{~m}$, and the cliff extends for more than 30 kilometers, making up a unique coastal landscape. The lake's bays are the best places for building and for settlements; Wase and Haidong towns are situated in bays. In addition, Luoquan Temple and Wenbi tower are located at the most promi- nent cape on the lake, near Haidong Town. These religious buildings and local residences are scattered across the landscape, and these reveal the context of the local culture. There are two isolated islands near Haidong Town and Wase Lake bay: Jinsuo Island and Xiaoputuo Island, where people from the Bai ethnic group exhibit their culture and religion. In short, the eastern shore area is a special place, with an historical cultural landscape which includes a combination of lake-eroded landforms, the culture of the Bai ethnic group and local religious constructions.

\section{Geomorphologic Characteristics Surrounding Cangshan Mountain}

The Haidong Mountains, to the east of Erhai Lake, are a series of small mountains and hills shaped by fluvial process. The rocks in the area are composed mainly of Ordovician shale and sandstone, Silurian limestone and shale, Carboniferous limestone and Permian basalt. The area near Erhai Lake is dominated by small hills 2100 to $2600 \mathrm{~m}$ in height, formed by water erosion. The strata incline to west, thus building the formation of the Cangshan block as a small anticline, with the Erhai depression as a large syncline. The higher surface, at about 2400 to $2600 \mathrm{~m}$ in height, is a larger, more continuous peneplain which represents the remnants of an ancient planation surface, and the relief on the planation surface divides the Erhai and Binchuan Basins, and this has moved to the west due to gradual westwards erosion of the Binchuan River. The water level of Erhai Lake (at $1900 \mathrm{~m}$ ) is $300 \mathrm{~m}$ higher than the average altitude of Binchuan Basin, so this topography has been used to divert water from Erhai to Binchuan since the 1990s (Figure 3).

Huadian Basin is located between the Cangshan, Yanjing, Yunnong and Canglang summits, and extends from $35 \mathrm{~km}$ from the north-west to the south-east, at an altitude of about $3000-3300 \mathrm{~m}$; at the conjunction of the Erhai Lake Basin and the Eryuan Basin. The basin has an anisomerous shape, the southwest slope is gentle with a long, extended alluvial deposition fan, while the northeast slope is steeper with no fan deposition. Most of the rivers' sources are in the southwestern mountains and flow to the northeast. There is very thick Quaternary sediment in the Huadian basin, which is a fault controlled graben valley; the thick, loose Quaternary deposits are alluvial and there is slope deposition on the western slope. This sediment was produced by glacial mechanical weathering and freeze-thaw mud flow processes. The fan was formed and continues to be formed by water flowing along the western slopes of the valley, so the course of the rivers there are gradually moving westwards. The landforms in the Huadian basin have been 
created by river capture between the Huadian River and Fengyu River, and this river capture process is still in progress today (Figure 3).

\section{Discussions}

The glacial erosion geomorphology at different altitudes is proof of the division in glaciation processes between the Lijiang and Dali ice ages. The Dali glacial cirque, crosswall and short-valley were originally distributed between about 3750 and $3900 \mathrm{~m}$. In the absence of glacial deposit landforms, glacial landforms as represented by the erosion cirques should be evidence of the existence of a Dali Ice Age. The cirque lake at Luoping Mountain was originally distributed regularly along the both sides of the main ridges. Shaped by water erosion and other external forces over a long period, the area reveals mixed rounded peaks and beams, and hilly areas like the landscape on China's the Loess Plateau. The ancient glaciers were formed at an elevation of 2900 to $3200 \mathrm{~m}$, about 750 to $800 \mathrm{~m}$ lower than the Dali Glaciation snow line, and earlier than the Dali Ice Age at Cangshan Mountain. The u-shaped valley which extends forward for three kilometers, and the obvious lateral moraine, should be evidence of the existence of the Lijiang Ice Age. As a result, there is not only evidence for the well-known scientific concept of a Dali glaciation in the Cangshan area, but also an earlier Late Pleistocene glaciation - the penultimate glaciation, known to us as the Lijiang Ice Age in the Dali area.

The altitude of Cangshan Mountain is higher than that of Luoping Mountain, but glacial erosion and depositional geomorphology earlier than the Dali Ice Age has not been found at Cangshan, so it cannot be determined whether or not there was a penultimate glaciation at Cangshan. All these facts have therefore created a mystery in the field of Quaternary glacial research; an incentive to promote the continuation of scientific work to explore this area.

\section{Conclusions}

The landforms in the area of Cangshan and Erhai Lake are characterized by diverse compositions on a multiple level, with fusions in the landscape. Though the region is small, the landform types are comprehensive, complex and changeable. There is a disaggregation of the Paleoplanation surface, lacustrine depositions on the western shores of the lake and erosion cliffs on the eastern shore; plus river terraces and evidence of mountainous glacial and periglacial processes. There is no doubt that Cangshan Mountain is the best place to research geomorphology and neo-tectonic movements in the region.
The summit of Cangshan is at a height of $3700 \mathrm{~m}$, a remnant of the paleoplanation surface, and its development was contemporaneous with Yulong Snow Mountain, at about $5000 \mathrm{~m}$ in height in Lijiang, as well as the surface of the Tibetan Plateau - at about $4500 \mathrm{~m}$.

There have been two glaciations on Cangshan Mountain, and there is evidence of glacial and periglacial processes having taken place in the area above $3500 \mathrm{~m}$, during the process of the uplift of the mountain. The scale of the two glaciations can be identified by the quantity, scale, distribution and height of the cirques, and their ages are $5.76 \times 10^{4} \mathrm{aBP}$ and $1.6 \times 10^{4} \mathrm{aBP}$, respectively.

There are three large erosion surfaces on Cangshan Mountain, which were formed by the phased uplift of the mountain. Three mixed deposition fans were formed on the eastern slope of the mountain, which are composed of debris flows, water-rock flows; fluvial, alluvial and slope depositions.

The mountainous area of east Erhai is the remnant of a planation surface at about $2500 \mathrm{~m}$, which is the best preserved planation surface in the Dali area. This is of great significance for the research of neo-tectonic movements in the western Yunnan block, and the Huadian basin was formed by the regional fault at the mountain. Thick and loose Quaternary sediments were deposited in the basin, and since that time, river capture has been the ongoing geomorphologic process to have influenced landform evolution in the basin.

The Dali glaciation and Cangshan Mountain are very important subjects to research in terms of the environment and glacial geology in the area, and our research offers a further level of understanding on the relationship between the evolution of landforms and glaciers in the area around Cangshan Mountain, through the field and laboratory work we carried out based on former studies [22-23].

\section{References}

[1] Z. W. Cheng and W. Ye. "The Necessity and Emergency of Study on Yunnan Dali Glaciation," Yunnan Geographic Environment Research, Vol. 5, No. 2, 1993, pp. 84-85.

[2] H. V. Wissmann, "The Pleistocene Glaciation of China," Bulletin of the Geological Society of China, Vol. 17, No. 2, 2007, pp. 145-168. doi:10.1111/j.1755-6724.1937.mp17002002.X

[3] J. J. Li "The Thesis Atlas of Academician-The Uplift of Tibet Plateau and Environmental Changes of Asia," Science Press, Beijing, 2006, pp. 1-200.

[4] W. C. Zhao, "Study on the Geomorphic System of Yunnan,” Yunnan Geographic Environment Research, Vol. 10, Supplement, 1998, pp. 47-55. 
[5] W. Credner, "The Expedition Report of Yunnan Geography in 1930," Natural Science, Vol. 3, No. 4, 1932, pp. 593-662.

[6] Bureau of Geology and Mineral Resources of Yunnan Province, "Yunnan Province Regional Geological Annals of Yunnan Province,” Geological Press, Beijing, 1990, pp. 1-220.

[7] J. L. Feng, "The Physiography of Dali County, Yunnan," Collected Papers of Geographic Research Institute of Chinese Academy of Sciences, No. 1-2, 1941, pp. 23-56.

[8] F. B. Chen, J. L. Chen and Y. F. Xu, "The Analysis of Neotectonics of Quaternary Accumulation and Layer Landforms in Yulongxueshan-Cangshan Areas," Acta Geographic Sinica, Vol. 47, No. 5, 1992, pp. 431-440.

[9] J. J. Li, Q. Shu, S. Z. Zhou, et al., "Review and Prospects of Quaternary Glaciation Research in China," Journal of Glaciology and Geocryology, Vol. 26, No. 3, 2004, pp. 235-243.

[10] Chengdu Geographic Institute of Chinese Academy of Sciences, "Geographic Information of Hengduanshan Mountianous Area-Geomorphological Part,” Research Report, 1980, pp. 14-26.

[11] P. H. Huang, "Discussing the Geomorphological Research on Yunnan,” Quaternaria Sinica, Vol. 3, No. 1, 1960, pp. 10-17.

[12] J. J. Li, S. X. Wen and Q. S. Zhang, “A Discussion on Ages, Extents and Forms of the Upheavalling of Qinhai Xizang Plateau," Science in China, No. 6, 1976, pp. 608616.

[13] M. Ren, et al., "A Primary Study on of Lijiang and Yulongshan Mountain," Yunnan University Transaction (Natural Science), No. 4, 1957, pp. 9-18.

[14] Y. F. Shi, et al., "Problems of Quaternary Glaciers and Environment in East China,” Science Press, Beijing, 1989, pp. 106-107.

[15] Y. F. Shi, "A Suggestion to Improve the Chronology of Quaternary Glaciations in China,” Journal of Glaciology and Geocryology, Vol. 24, No. 6, 2002, pp. 687-692.

[16] Q. L. Chen and W. C. Zhao, “Aerial Images Observation of Glacial Landforms at Cangshan Mountain, Dali, Yunnan,” Yunnan Geographic Environment Research, Vol. 9, No. 2, 1997, pp. 66-73.

[17] Y. Feng and D. M. He, "The Precipitation Characteristics and Water Resources Utilization in High Mountain and Deep Gorge Area in Northwest Yunnan Province," Yunnan Geographic Environment Research, Vol. 9, No. 1, 1997, pp. 40-47.

[18] M. S. Kuang and W. C. Zhao, "Study on ESR Dating of Depositional Stratums of Late Pleistocene Epoch in Cangshan Mountain, Dali Area, Yunnan Province," Yunnan Geographic Environment Research, Vol. 9, No. 1, 1997, pp. 49-57.

[19] S. Z. Zhou and J. J. Li, "New Dating Results of Quaternary Glaciations in China," Journal of Glaciology and Geocryology, Vol. 25, No. 6, 2003, pp. 660-666.

[20] R. F. Flint, “Glacial and Quaternary Geology,” John Wiley Press, New York, 1971, p. 423.

[21] Z. Q. Zhang, "A Study on the Relationship between Regional Earthquake and Modern Tectonics Movement,” Seismology and Seismological Archaeology, Cultural Relic Press, Beijing, 1977, pp. 109-130.

[22] Glaciology and Geocrology Institute, Chinese Academy of Sciences, “The Outline of Chinese Glaciers," Science Press, Beijing, 1988, pp. 1-186.

[23] Y. F. Shi and Z. C. Xie, "The Basic Characteristics of Modern Glacier of China,” Acta Geographic Sinica, Vol. 30, No. 3, 1964, pp. 183-208. 